\title{
CHARACTERISATION OF BACTERIAL DIVERSITY IN FRESH AND AGED SEWAGE SLUDGE BIOSOLIDS USING NEXT GENERATION SEQUENCING
}

\author{
Karen R. Little ${ }^{1}$, Han Ming Gan ${ }^{2}$, Aravind Surapaneni ${ }^{3}$, Jonathan Schmidt ${ }^{3}$ and \\ Antonio F. Patti ${ }^{1, *}$ \\ ${ }^{1}$ School of Chemistry, Monash University, Clayton, VIC 3800, Australia \\ ${ }^{2}$ School of Life and Environmental Sciences, Deakin University, Geelong, VIC 3220, Australia \\ ${ }^{3}$ South East Water, Frankston, VIC 3199, Australia
}

Article Info:
Received:
11 August 2019
Revised:
23 January 2019
Accepted:
27 January 2020
Available online:
5 March 2020
Keywords:
Biosolids
Sewage sludge
Bacteria
Next generation sequencing

\section{INTRODUCTION}

Australia produces approximately 300,000 tonnes of dry sewage sludge biosolids annually. Approximately $55 \%$ of this is applied to agricultural land, $30 \%$ stored in landfill and $15 \%$ is composted, used for land rehabilitation, landscaping or incinerated (Australian \& New Zealand Biosolids Partnership, 2016).

The agricultural benefits of applying biosolids to soil are the addition of nutrients, particularly nitrogen and phosphorus and to increase organic matter. Beneficial effects have been demonstrated on crop yield and nutrition (Cooper, 2005; Ferraz, Momentel, \& Poggiani, 2016; Petersen, Petersen, \& Rubæk, 2003; Warman \& Termeer, 2005) and soil physicochemical properties (Bevacqua \& Mellano, 1993; Gómez-Muñoz, Magid, \& Jensen, 2017; Qiong, Li, Cui, \& Wei, 2012; Tamoutsidis, Papadopoulos, Tokatlidis, Zotis, \& Mavropoulos, 2002) in a range of soil and crop types.
Advances in high-throughput $16 \mathrm{~S}$ rDNA amplicon sequencing technologies provide a considerable amount of taxonomic information and have changed our understanding of microbial diversity in the environment. Given the importance of microbes to influence crop growth and nutrient availability in soil, consideration needs to be given to the composition of the microbial community indigenous to the biosolids as well as effects on the soil microbial community following land application. A growing awareness of inoculation with plant growth promoting bacteria (PGPB) represents an important strategy for sustainable management and reduction of negative environmental impacts. Within the broad range of PGPB, the Proteobacteria phylum is the most represented, with a number of bacteria classified to this phylum capable of forming symbiotic relationships with leguminous plants. Some of these bacteria are also capable of producing phytohormones (Hershey, Lu, Zi, \& Peters, 2014; Nagel, Bieber, Schmidt-Dannert, Nett, \& Peters, 2018) and solubilizing inorganic phosphate (Z. Dai et 
al., 2019), thereby promoting plant growth in a number of ways.

A number of studies have focused on pathogen detection and abundance in biosolids (Bibby \& Peccia, 2013; Bibby, Viau, \& Peccia, 2010; Irwin et al., 2017; Karpowicz, Novinscak, Bärlocher, \& Filion, 2010; Rouch, Fleming, Deighton, Blackbeard, \& Smith, 2008; Viau \& Peccia, 2009a, 2009b; Yergeau et al., 2016), risks to human health during land application due to bioaerosol generation (Herrmann, Grosser, Farrar, \& Brobst, 2017; Paez-Rubio et al., 2007), and effects on the indigenous soil microbial community following land application (Hu, Pang, Yang, Zhao, \& Cao, 2019; Mossa, Dickinson, West, Young, \& Crout, 2017; Schlatter et al., 2019). To our knowledge, identification of bacterial diversity in biosolids of different ages and more importantly identification of agriculturally beneficial bacteria in biosolids stockpiles has not been investigated.

The aims of this study were:

- To investigate the bacterial diversity and community composition of the biosolids from a wastewater treatment plant, ranging from freshly dewatered sludge to that stockpiled for a period of four years.

- To identify if agriculturally relevant bacteria (PGPB) were present in the aged biosolids.

\section{MATERIALS AND METHOD}

\subsection{Biosolids collection}

The Boneo wastewater treatment plant is located 83 $\mathrm{km}$ from Melbourne, on Victoria's Mornington Peninsula. The plant accepts domestic wastewater and tankered waste including leachate from the local landfill sites and serves a population equivalent of approximately 47,800 people. The annual median inflow of domestic wastewater to the plant is $10 \mathrm{ML}$ day-1, however, there is significant seasonal variation due to the number of holiday homes in the area. Wastewater treatment is via a twin stream activated sludge process. Waste activated sludge from the bioreactors is drawn from the return activated sludge (RAS) underflow from the clarifiers and treated via aerobic digestion for approximately 10 days. The treated sludge is transferred to an anaerobic storage lagoon for further digestion to reduce volatile solids. Most of the sludge from the anaerobic lagoon is pumped to a continuously mixed storage tank of approximately $10 \mathrm{~m} 3$ capacity that supplies feed sludge to the belt press for dewatering. Dewatered sludge from the belt press is conveyed into one of the three enclosed solar drying sheds where it is distributed over the drying floor by a mechanical tiller and dried to $>50 \%$ dry solids. After a predetermined period of time, equivalent to three months in summer and ten months during the winter season, the sludge is harvested and transported to the biosolids stockpile area. Surplus sludge from the anaerobic lagoon that exceeds the capacity of the belt press/ solar drying shed route is pumped to an open-air sludge drying pan. After approximately one year in the drying pan the sludge is removed, usually at the end of summer when the sludge is at its driest, and transported to the biosolids stockpile area. Once stockpiled, the biosolids remain in a static state without mechanical turning or aeration. Typically, the dried sludge from the sludge drying pan and the solar dryers from the Boneo wastewater treatment plant is stockpiled for greater than three years to achieve the highest treatment grade (Grade T1). The treatment grades in accordance with the Environmental Protection Authority (EPA) Publication 943 (EPA Victoria, 2004) are determined according to three main criteria: (i) adoption of a prescribed treatment process with minimum performance criteria (e.g. temperature/time); (ii) microbiological limits to demonstrate that the treatment processes are operating effectively; and (iii) measures for controlling bacterial regrowth, vector attraction and generation of nuisance odours. Grade T1 (< 100 Eschericia g-1 dry solids, < 1 Salmonella spp. $50 \mathrm{~g}-1$ dry solids, $\leq 1$ enteric virus $100 \mathrm{~g}-1$ dry solids) represents the highest quality grade and from a microbiological perspective is suitable for unrestricted use, whereas restrictions on end use apply to T2 and T3 biosolids (EPA Victoria, 2004). Recently, Irwin et al (2017) verified the sludge treatment processes at the Boneo wastewater treatment plant and concluded that this plant achieved T1 grade biosolids with respect to prescribed log reductions for a range of pathogens ( $>3 \log 10$ enteric virus and $>2$ $\log 10$ Ascaris ova in addition to achieving the $\mathrm{E}$. coli and Salmonella criteria as above), after a stockpiling/storage period of one year. Shortening the storage time from three years to one year reduces overall site odour potential, improves site aesthetics as well as reduces the total area of land required for stockpiling. Only biosolids from the solar dryer route were investigated in this study as biosolids from the drying pans are inadvertently mixed with clay liner from the drying pan during harvest.

The biosolids stockpile sampling equipment was decontaminated using the Environmental Protection Agency Victoria (EPA) approved triple wash procedure (Extran ${ }^{\circledR}$ solution followed by rinsing with tap water then de-ionised water), between each sample core to avoid cross-contamination. Disposable gloves and boot covers were worn during the sampling of stockpiles and were replaced between each sample location within a stockpile. Samples were placed into sterile bags and stored on ice. Upon arrival at Monash University they were stored at $-20^{\circ} \mathrm{C}$ until physicochemical analysis and DNA extraction were performed

The biosolids samples were collected from five points within the sludge treatment process and identified according to the period of time elapsed post-dewatering. The first sampling point was at the conveyor belt, which transported the dewatered biosolids into the solar drying shed. Six grab samples of approximately $250-300 \mathrm{~g}$ each were combined to form a composite sample of approximately $1.6 \mathrm{~kg}$, which was identified as week $0(\mathrm{t}=0)$. The second sampling point was in the solar drying shed, furthest away from the incoming dewatered sludge, where the biosolids had been turned and dried by mechanical tillering for one week. Six grab samples of approximately 150-200 g each were collected from the width of the shed floor and combined to form a composite sample of approximately $1.1 \mathrm{~kg}$. This sample was identified as week $1(t=1)$. Over a period of time, the biosolids are moved from the drying shed to outdoor stockpiles. Prior to transporting the biosolids to 
the stockpile area, six grab samples of approximately 200 $\mathrm{g}$ each were collected and combined to form a composite sample of approximately $1.2 \mathrm{~kg}$, which was identified as week $2(t=2)$. Portable percussion sampling equipment was used to collect cores from biosolids stockpiles which had been established in 2015 and 2012, with biosolids additions made to each stockpile within that year. Five replicate cores were collected from regular intervals along the length of each stockpile. Once the sample had been extruded from the coring tool, a portion of biosolids was retained from depths of 0.7 and $1.5 \mathrm{~m}$ from the 2015 stockpile, and $1.5 \mathrm{~m}$ and $2 \mathrm{~m}$ from the 2012 stockpile. These depths represented mid-depth and $1 \mathrm{~m}$ from the base of the pile and will be collectively referred to henceforth as Depth 1 and Depth 2, respectively. Biosolids sampled from the 2015 and 2012 stockpiles will be referred to as 52 weeks and 208 weeks, respectively. The total number of biosolids samples collected from the site was 23 ( 1 each from 0,1 and 2 weeks, 10 from 52 weeks and 10 from 208 weeks). All of the biosolids were collected on the same day (26th October 2016). The waste-water treatment process at the site hasn't changed since 2012 hence it is justifiable to compare the fresh biosolids (0, 1 and 2 weeks) to the 2015 (52 weeks) and 2012 (208 weeks) biosolids.

\subsection{Biosolids physiochemical properties}

The $\mathrm{pH}$ and $\mathrm{EC}$ of the biosolids were determined in $5 \mathrm{~g}$ sub samples suspended in deionised water (1:5 W/V) following shaking for $1 \mathrm{~h}$ using a TPS WP81 meter and probe (TPS Pty Ltd, Springwood, QId). Total C and N were determined by dry combustion (Vario microcube, Elementar). Approximately $5 \mathrm{~g}$ of each sample was dried at $105^{\circ} \mathrm{C}$ for $48 \mathrm{~h}$ and moisture loss determined from the loss of mass before and after drying. A portion of each sample was submitted to ALS, Scoresby, Victoria for ammonium, nitrate, Olsen $\mathrm{P}$ and total $\mathrm{K}$ analysis.

\subsection{DNA extraction and sequencing analysis}

Genomic DNA was extracted from each biosolids sample in triplicate using the PowerSoil@ DNA Isolation Kit (MoBio Laboratories, Carlsbad, CA), following the manufacturer's procedure with the only exception being a double wash with Solution C5 on the spin filter prior to DNA elution. Yields and purity of the DNA were determined by NanoDrop (Thermoscientific) at 260 and $280 \mathrm{~nm}$. PCR amplification was carried out on the purified DNA ( 20 ng input) using KAPA HiFi HotStart ReadyMix (Kapa Biosystems, South Africa) and primers targeting the V3V4 region of microbial 16S rRNA gene. (Bartram, Lynch, Stearns, Moreno-Hagelsieb, \& Neufeld, 2011; Klindworth et al., 2012). The forward and reverse primers were synthesized to contain partial Illumina adaptor sequence on their $5^{\prime}$ ends (TCGTCGGCAGCGTCAGATGTGTATAA_GAGACAG and GTCTCGTGGGCTCGgAGATGTGTATAAGAGACAG for forward and reverse primers, respectively) that enable the addition of Illumina dual index barcode in the second PCR step. The first PCR conditions involved an initial denaturation step at $95^{\circ} \mathrm{C}$ for 3 min followed by 25 cycles of $95^{\circ} \mathrm{C}$ for $30 \mathrm{sec}, 55^{\circ} \mathrm{C}$ for $30 \mathrm{sec}$ and $72^{\circ} \mathrm{C}$ for $30 \mathrm{sec}$ and ended with an extension step at $72^{\circ} \mathrm{C}$ for $5 \mathrm{~min}$. The PCR prod- ucts were purified using $0.8 \times$ volume of AmpureBead XP (Beckman Coulter, Danvers, MA) and were then used as the template for the second PCR step with similar cycling condition followed by another round of purification using $0.6 x$ volume of AmpureBead XP (Beckman Coulter, Danvers, MA). Each library was individually quantified using Qubit dsDNA BR Assay Kit (Invitrogen, Santa Clara, CA), normalized, pooled, denatured and sequenced on the MiSeq $(2 \times$ 250 bp paired-end run) located at the Monash University Malaysia Genomics Facility.

\subsection{Bioinformatics}

Primer sequences were trimmed from the $5^{\prime}$ end of each read using cutadapt version 1.14 (Martin, 2011). The trimmed pair-end reads were quality-trimmed and merged using the fastq_mergepairs command as implemented in USEARCH v9 (Edgar \& Flyvbjerg, 2015). The overlapped reads were subsequently dereplicated, clustered at $97 \%$ identity cut off and chimera-filtered using UPARSE (Edgar, 2013). Taxonomy assignment, abundance estimation, and diversity metric calculation were performed using QIIME 1.8 (Caporaso et al., 2010).

\subsection{Statistical analysis}

Bacterial abundance data was arcsine transformed and the normality assessed by the Sharpiro-Wilk test. At the phylum level of classification, phyla with less than $2 \%$ abundance were categorised as 'Other'. Significant differences in abundance at the phylum level between the biosolids of increasing age were identified by Kruskal-Wallis followed by pairwise comparisons by Dunn's multiple comparison test. Significant differences in the bacterial alpha diversity were identified by the Kruskal-Wallis test. Significant differences in the relative abundance of bacteria at the genus classification level were identified by Analysis of Similarities (ANOSIM) with Bray Curtis distance index and genera contributions to dissimilarity identified by Similarity Percentage analysis (SIMPER). Shared operational taxonomic units (OTUs) were identified using the "compute_core_microbiome.py" command (default setting) in QIIME and the Venn diagram constructed using VENNY (Oliveros, 2015).

The normality of the biosolids physicochemical data was assessed by the Shapiro-Wilks test and significant differences were identified by ANOVA and Tukey's Honestly Significant Difference (HSD) using IBM SPSS Statistics for Windows, Version 23.0. Armonk, NY: IBM Co. Canonical correspondence analysis was used to identify the physicochemical properties associated with changes in bacterial abundance and Spearman's rank-order correlation was used to confirm the relationship using PAST - Paleontological statistics software package for education and data analysis.

\section{RESULTS}

\subsection{Relative bacterial abundance at the phylum level of classification}

The allocation of sequences to phyla is generally considered robust, particularly if correction procedures are implemented to remove biases and errors (Edgar, 2013; Edgar 


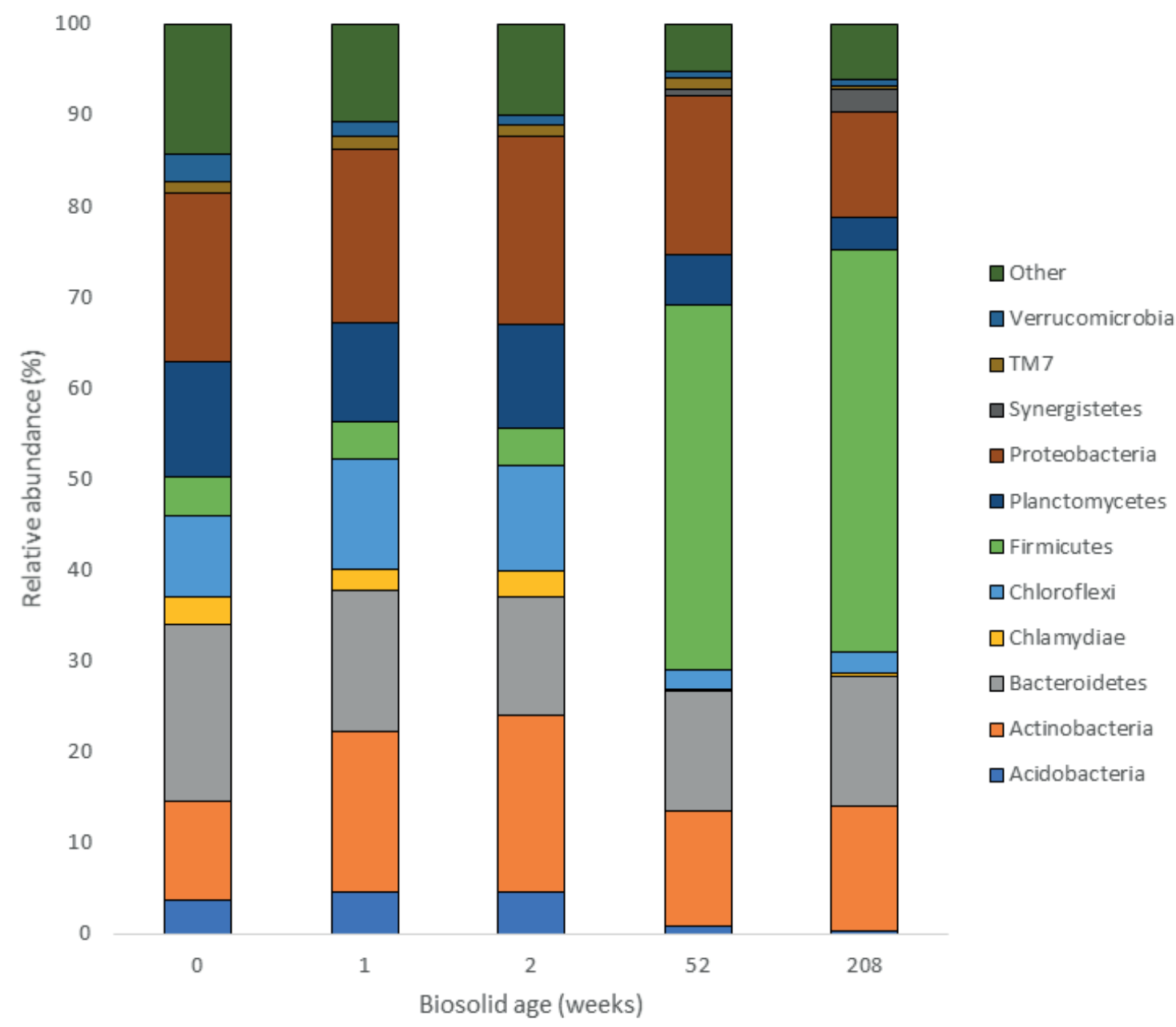

FIGURE 1: Relative abundance of the bacterial phyla in the biosolids according to age (weeks) irrespective of sampling depth. Phyla with less than $2 \%$ of the overall abundance were categorised as Other.

\& Flyvbjerg, 2015). Irrespective of the sampling depth and biosolids age, the dominant phyla were Firmicutes, Actinobacteria, Bacteroidetes and Proteobacteria. (Figure 1). The phyla Acidobacteria Chlamydiae, Planctomycetes, Synergistetes, TM7 and Verrucomicrobia were also detected but at lower abundances. The most dramatic increase was in the abundance of Firmicutes which increased ten-fold from $4.2 \%$ in the fresh biosolids to 40 to $44 \%$ in the stockpiled biosolids. The abundance of Actinobacteria was variable, with no clear trend, ranging from 10.9 to $19.3 \%$ and the abundance of Proteobacteria decreased with stockpiling from 18.5 to $20.4 \%$ in the fresh biosolids to $11.5 \%$ in the stockpiled biosolids.

The abundance of the less dominant phyla Acidobacteria, Chlamydiae, Chloroflexi, Planctomycetes and Verrucomicrobia all decreased significantly with increasing biosolids age. The abundance of Synergistetes increased significantly with biosolids stockpiling time from $0.13 \%$ in the fresh biosolids to $2.5 \%$ in the stockpiled biosolids. There were significant differences in the relative abundance of phyla with biosolids age, with the exception of Bacteroidetes (Table 1).

The relative abundance of each phylum at the two sampling depths was determined in the stockpiled biosolids (52 and 208 weeks). Within the 52 weeks stockpile there were significant decreases in Acidobacteria, Proteobacteria and Planctomycetes with increasing depth (Table 2). There were significant increases with depth in the abundance of Firmicutes and Synergistetes. In the 208 weeks stockpile, there were significant increases in Acidobacteria, Actinobacteria, Bacteroidetes, Chlamydiae, Planctomycetes, and TM7 with increasing depth. There were significant decreases in Bacteroidetes, Synergistetes, and Verrucomicrobia phyla.

\subsection{Bacterial alpha diversity}

Bacterial alpha diversity significantly decreased with increasing age of the biosolids as indicated by chao 1 $(p<0.01)$, observed OTUs $(p<0.01)$ and Shannon index $(p<0.01)$ (Figure 2). For each measure of alpha diversity, there was no significant difference between the 52 and 208 weeks old biosolids. There were significant differences between all other pairwise combinations.

\subsection{Biosolids physicochemical properties}

The $\mathrm{pH}$ of the biosolids was significantly higher in the older stockpiled biosolids compared to the fresh biosolids, ranging from 8.21 to 6.93 , respectively (Table 3 ). There was a significant increase in the ammonium content of the bio- 
TABLE 1: Pairwise comparisons of the relative abundance of bacterial phylum in the fresh (0, 1 and 2 week) and stockpiled (52 and 208 weeks) biosolids as determined by Kruskal-Wallis followed by Dunn's multiple comparison test. The abbreviation 'ns' refers to not significant. * $p<0.05,{ }^{* *} p<0.01$

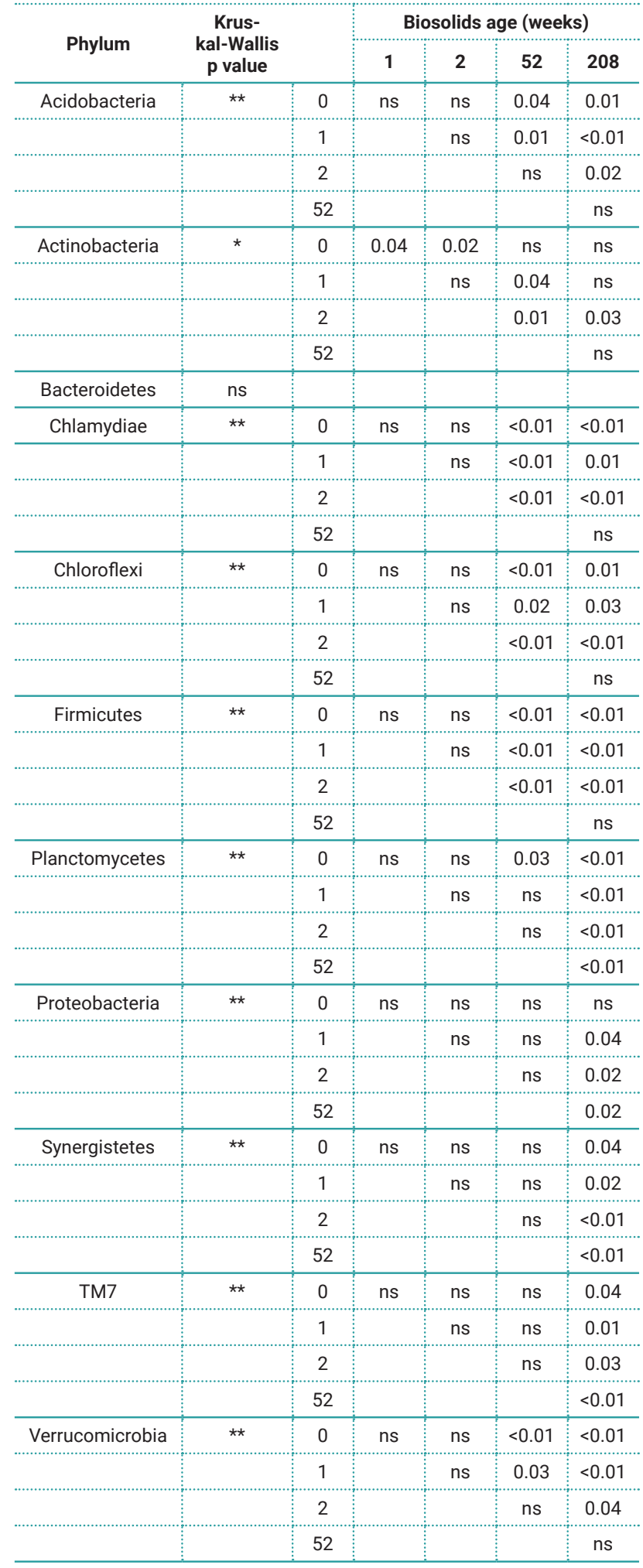

solids with stockpiling, with $801 \mathrm{mg} / \mathrm{kg}$ in the fresh biosolids compared to up to $8,178 \mathrm{mg} / \mathrm{kg}$ in the stockpiled biosolids. Analysis by ANOVA indicated significant differences in nitrate between the biosolids but this was not significant
TABLE 2: Bacterial phylum relative abundance at two depths in the 52 and 208 weeks old biosolids stockpiles. The values presented are Kruskal-Wallis mean rank. The abbreviation 'ns' refers to not significant. * $p<0.05$, ** $p<0.01$

\begin{tabular}{|c|c|c|c|c|}
\hline $\begin{array}{l}\text { Biosolids age } \\
\text { (weeks) }\end{array}$ & Bacterial phylum & Depth 1 & Depth 2 & $p$ value \\
\hline \multirow[t]{11}{*}{52} & Acidobacteria & 16.00 & 14.33 & $\star \star$ \\
\hline & Actinobacteria & 17.29 & 11.33 & ns \\
\hline & Bacteroidetes & 14.48 & 17.89 & ns \\
\hline & Chlamydiae & 14.26 & 18.39 & ns \\
\hline & Chloroflexi & 13.95 & 19.11 & ns \\
\hline & Firmicutes & 15.14 & 16.33 & $\star \star$ \\
\hline & Planctomycetes & 15.62 & 15.22 & $\star *$ \\
\hline & Proteobacteria & 15.90 & 14.56 & $\star *$ \\
\hline & Synergistetes & 14.38 & 18.11 & * \\
\hline & TM7 & 17.38 & 11.11 & * \\
\hline & Verrucomicrobia & 14.67 & 17.44 & ns \\
\hline \multirow[t]{11}{*}{208} & Acidobacteria & 10.47 & 20.53 & $\star *$ \\
\hline & Actinobacteria & 10.00 & 21.00 & ** \\
\hline & Bacteroidetes & 19.40 & 11.60 & $\star *$ \\
\hline & Chlamydiae & 12.13 & 18.87 & $\star *$ \\
\hline & Chloroflexi & 14.67 & 16.33 & ns \\
\hline & Firmicutes & 14.07 & 16.93 & ns \\
\hline & Planctomycetes & 9.83 & 21.17 & $\star *$ \\
\hline & Proteobacteria & 14.93 & 16.07 & ns \\
\hline & Synergistetes & 12.00 & 10.00 & $\star *$ \\
\hline & TM7 & 10.00 & 21.00 & $\star *$ \\
\hline & Verrucomicrobia & 18.67 & 12.33 & * \\
\hline
\end{tabular}

by Tukey's HSD due to the conservative nature of the analysis. There were no significant changes in Olsen $\mathrm{P}$, total $\mathrm{N}$, total $\mathrm{C}$ or $\mathrm{K}$ with stockpiling. There was a significant decrease in moisture with stockpiling. Canonical Correspondence Analysis (CCA) (Figure 3) indicated that the change in abundance of Firmicutes may have been influenced by ammonium concentration and total $\mathrm{K}$. This was indicated by the close proximity of Firmicutes abundance to the quantitative explanatory variables ammonium and total $\mathrm{K}$, in the direction of increasing concentration. Spearman correlation confirmed this, with ammonium content being the main driver of Firmicutes abundance changes and less so influenced by $\mathrm{pH}, \mathrm{K}$ and total $\mathrm{N}$ (Table 4).

\subsection{Genera in the Firmicutes phylum}

Analysis by ANOSIM with Bray-Curtis distance index indicated that at the genus classification, the composition of the Firmicutes phylum in the fresh (weeks 0, 1 and 2 combined) biosolids was significantly different to that of the stockpiled (weeks 52 and 208 combined) biosolids (Table 5). Pairwise comparison indicated significant differences in Firmicutes community composition with depth in 52 weeks biosolids stockpile while the composition of the 208 weeks stockpile is more consistent.

Bacteria community compositional differences were identified by SIMPER. Only genera that contributed to greater than $5 \%$ dissimilarity have been reported. Comparisons were made between the composition of the fresh biosolids 

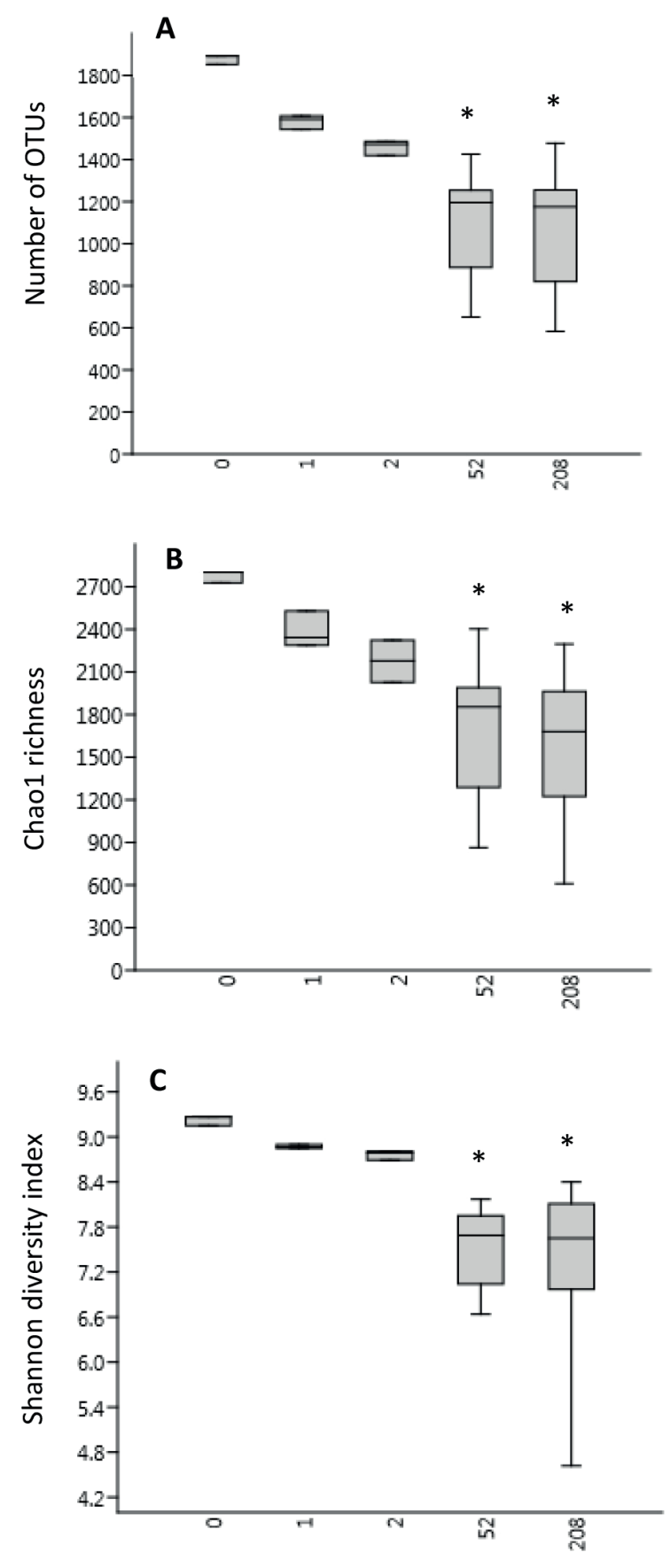

Biosolid age (weeks)

FIGURE 2: Observed OTUs (A), Chao1 (B) and Shannon index (C) of the fresh (0, 1 and 2 week) and stockpiled (52 and 208 weeks) biosolids. * indicates that these values are not significantly different by Dunn's Multiple Comparison test. All other pairwise combinations are significantly different.

and the 52 weeks biosolids at sampling depth 1. The largest contributor to dissimilarity was Tepidimicrobium with $19.53 \%$ contribution, increasing in abundance from 0.08 to $11.10 \%$, respectively (Table 6 ). Bacillus accounted for a $15.4 \%$ contribution, followed by Caldicoprobacter (11.08\%), Anoxybacillus (6.78\%), Desulfotomaculum (6.32\%) and Paenibacillus (6.25\%).
TABLE 3: Physiochemical properties of the fresh and stockpiled biosolids. Mean values are presented and values in parentheses represent standard error. Values in rows with the same lower case letter are not significantly different at $\mathrm{p}=0.05$ as assessed by Tukey's HSD.

\begin{tabular}{|c|c|c|c|c|c|}
\hline & \multicolumn{5}{|c|}{ Biosolid age (weeks) } \\
\hline & Fresh & $\begin{array}{c}52 \\
\text { Depth } 1\end{array}$ & $\begin{array}{c}52 \\
\text { Depth } 2\end{array}$ & $\begin{array}{c}208 \\
\text { Depth } 1\end{array}$ & $\begin{array}{c}208 \\
\text { Depth } 2\end{array}$ \\
\hline $\mathrm{pH}$ & $\begin{array}{l}7.39^{\mathrm{b}} \\
(0.07)\end{array}$ & $\begin{array}{l}6.93^{c} \\
(0.22)\end{array}$ & $\begin{array}{l}8.10^{\mathrm{a}} \\
(0.03)\end{array}$ & $\begin{array}{l}8.21^{\mathrm{a}} \\
(0.02)\end{array}$ & $\begin{array}{l}8.01^{\mathrm{a}} \\
(0.02)\end{array}$ \\
\hline $\begin{array}{l}\text { Ammonium } \\
(\mathrm{mg} / \mathrm{kg})\end{array}$ & $\begin{array}{l}801^{c} \\
(71)\end{array}$ & $\begin{array}{l}4655^{\mathrm{b}} \\
(797)\end{array}$ & $\begin{array}{l}8178^{a} \\
(1424)\end{array}$ & $\begin{array}{l}7280^{a} \\
(440)\end{array}$ & $\begin{array}{l}6327^{\mathrm{ab}} \\
(439)\end{array}$ \\
\hline $\begin{array}{l}\text { Nitrate } \\
(\mathrm{mg} / \mathrm{kg})\end{array}$ & $\begin{array}{c}0.45 \\
(0.27)\end{array}$ & $\begin{array}{c}2444 \\
(1125)\end{array}$ & $\begin{array}{c}249 \\
(247)\end{array}$ & $\begin{array}{c}15 \\
(15)\end{array}$ & $\begin{array}{c}98 \\
(43)\end{array}$ \\
\hline $\begin{array}{l}\text { Total K } \\
(\mathrm{mg} / \mathrm{kg})\end{array}$ & $\begin{array}{l}2333 \\
(296)\end{array}$ & $\begin{array}{l}4040 \\
(517)\end{array}$ & $\begin{array}{l}3225 \\
(423)\end{array}$ & $\begin{array}{l}3840 \\
(287)\end{array}$ & $\begin{array}{l}3440 \\
(341)\end{array}$ \\
\hline $\begin{array}{l}\text { Olsen P } \\
(\mathrm{mg} / \mathrm{kg})\end{array}$ & $\begin{array}{l}2433 \\
(521)\end{array}$ & $\begin{array}{c}1232 \\
(98)\end{array}$ & $\begin{array}{c}3300 \\
(1903)\end{array}$ & $\begin{array}{l}1540 \\
(144)\end{array}$ & $\begin{array}{c}878 \\
(122)\end{array}$ \\
\hline $\begin{array}{l}\text { Total C } \\
(\%)\end{array}$ & $\begin{array}{l}21.57 \\
(2.65)\end{array}$ & $\begin{array}{l}25.31 \\
(2.69)\end{array}$ & $\begin{array}{l}28.01 \\
(1.58)\end{array}$ & $\begin{array}{l}21.60 \\
(0.87)\end{array}$ & $\begin{array}{l}20.62 \\
(1.38)\end{array}$ \\
\hline $\begin{array}{l}\text { Total N } \\
(\%)\end{array}$ & $\begin{array}{c}3.37 \\
(0.24)\end{array}$ & $\begin{array}{c}3.82 \\
(0.45)\end{array}$ & $\begin{array}{c}4.41 \\
(0.32)\end{array}$ & $\begin{array}{c}4.02 \\
(0.30)\end{array}$ & $\begin{array}{c}3.40 \\
(0.25)\end{array}$ \\
\hline $\begin{array}{l}\text { Moisture } \\
(\%)\end{array}$ & $\begin{array}{l}49.03^{a} \\
(2.25)\end{array}$ & $\begin{array}{l}34.07^{\mathrm{b}} \\
(1.91)\end{array}$ & $\begin{array}{l}32.62^{b} \\
(3.34)\end{array}$ & $\begin{array}{c}38.00^{\mathrm{ab}} \\
(2.47)\end{array}$ & $\begin{array}{l}38.77^{\mathrm{b}} \\
(1.31)\end{array}$ \\
\hline
\end{tabular}

Comparisons were made between the composition of the 52 weeks biosolids at sampling depths 1 and 2 (Table 7). Sporosarcina was the largest contributor to dissimilarity at $12.37 \%$ with an increase in the mean from 1.1 to $6.77 \%$, respectively. The next largest contributor was Bacillus at $11.63 \%$, followed by Caldicoprobacter (8.82\%) Tepidimicrobium (8.71\%), Anoxybacillus (6.01\%), Clostridium (5.90\%) and Geobacillus (5.87\%).

\subsection{Shared Operational Taxonomic Units (OTUs)}

Twelve OTUs were present in all of the collected biosolids, from fresh to stockpiled (Table 8). These were predominantly classified to the Proteobacteria phylum, with Actinobacteria and Firmicutes also represented.

\section{DISCUSSION}

Next generation sequencing was used to characterise the bacterial community in fresh, dewatered $(0,1$ and 2 weeks old) and stockpiled biosolids (52 and 208 weeks old). Significant shifts in the composition of the bacterial community with stockpiling were detected, correlating to changes in the physicochemical properties of the biosolids. To our knowledge this is the first culture-independent study of bacterial community shifts with physicochemical properties assessment over time comparing freshly dewatered biosolids to those stored in unmanaged stockpiles.

The dominant phyla identified in the fresh and stockpiled biosolids were similar to those detected in other studies, although in varying proportions (Bibby et al., 2010; Novinscak, Filion, Surette, \& Allain, 2008; Yergeau et al., 2016). Yergeau et al. (2016) found that in dewatered sludge, the dominant phyla were Bacteroidetes, Proteobacteria and Firmicutes, but a comparatively lower abundance of Actinobacteria. Conversely, Novinscak, DeCoste, Surette, and Filion (2009) demonstrated that in biosolids stored in 


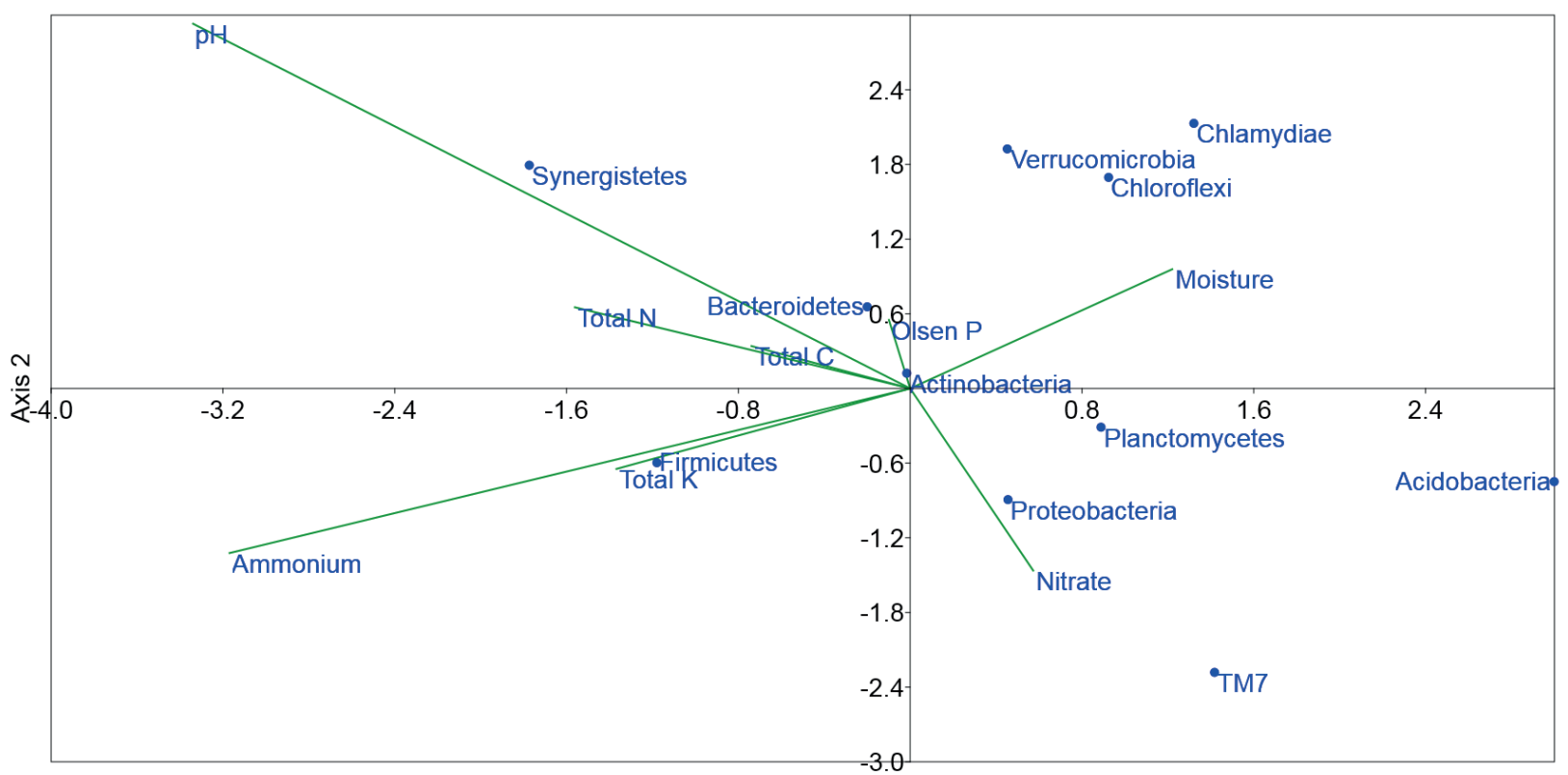

Axis 1

FIGURE 3: Canonical Correspondence Analysis (CCA) of the physicochemical properties of the biosolids regardless of age and the relative abundance of bacteria classified to the phylum level. The green lines indicate the direction of increase of each quantitative explanatory variable.

windrows, the abundance of Firmicutes decreased significantly with Proteobacteria becoming the dominant phyla however the management practices e.g. turning and aeration were not described. In comparison to the phyla identified in agricultural soils, depending on management practices, Proteobacteria would be expected to dominate the community with lower abundances of phyla including Ac- idobacteria, Actinobacteria, Verrucomicrobia, Bacteroidetes, Chloroflexi and Firmicutes, (Bibby et al., 2010; Janssen, 2006; Shange, Ankumah, Ibekwe, Zabawa, \& Dowd, 2012), The persistence and functionality of biosolids indigenous bacteria once applied to land would depend on a range of factors including environmental conditions, the crop and soil type and competition for resources from the soil indig-

TABLE 4: Spearman's rank order correlation coefficients. Values in bold highlight significant correlations where ** $\mathrm{p}<0.01$ and * $\mathrm{p}<0.05$.

\begin{tabular}{|c|c|c|c|c|c|c|c|c|}
\hline Phylum & $\mathrm{pH}$ & $\begin{array}{c}\text { Ammonium } \\
(\mathrm{mg} / \mathrm{kg})\end{array}$ & $\begin{array}{c}\text { Nitrate } \\
(\mathrm{mg} / \mathrm{kg})\end{array}$ & $\begin{array}{c}\mathrm{K} \\
(\mathrm{mg} / \mathrm{kg})\end{array}$ & $\begin{array}{l}\text { Olsen P } \\
(\mathrm{mg} / \mathrm{kg})\end{array}$ & $\begin{array}{l}\mathrm{C} \\
(\%)\end{array}$ & $\begin{array}{c}N \\
(\%)\end{array}$ & $\begin{array}{c}\text { Moisture } \\
\text { (\%) }\end{array}$ \\
\hline Acidobacteria & -0.81 ** & $-0.83^{\star \star}$ & 0.34 & -0.31 & -0.031 & -0.28 & $-0.53^{\star \star}$ & 0.17 \\
\hline Actinobacteria & -0.12 & -0.27 & 0.09 & -0.26 & -0.24 & -0.20 & -0.38 & 0.15 \\
\hline Bacteroidetes & 0.14 & -0.26 & -0.15 & -0.05 & 0.30 & 0.34 & 0.46 & 0.04 \\
\hline Chlamydiae & -0.09 & -0.54 ** & -0.38 & $-0.54 * \star$ & 0.06 & 0.07 & -0.25 & $0.44 *$ \\
\hline Chloroflexi & -0.20 & $-0.61 * *$ & -0.50 & -0.23 & 0.15 & 0.03 & -0.15 & 0.40 \\
\hline Firmicutes & $0.57^{* *}$ & $0.81^{* *}$ & -0.18 & $0.49 *$ & -0.06 & 0.23 & $0.46^{*}$ & -0.35 \\
\hline Planctomycetes & $-0.68^{\star *}$ & $-0.73^{\star \star}$ & $0.44^{\star}$ & $-0.46^{\star}$ & -0.12 & 0.02 & $-0.46^{\star}$ & 0.18 \\
\hline Proteobacteria & $-0.62 * \star$ & $-0.43^{\star *}$ & 0.17 & -0.28 & -0.04 & -0.29 & $-0.52^{\star}$ & 0.27 \\
\hline Synergistetes & $0.70 * \star$ & $0.67^{* *}$ & $-0.69 * *$ & 0.28 & -0.04 & 0.02 & 0.37 & -0.08 \\
\hline TM7 & 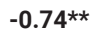 & $-0.64 \star \star$ & $0.67 \star \star$ & -0.37 & -0.17 & -0.05 & $-0.47^{\star}$ & 0.05 \\
\hline Verrucomicrobia & -0.01 & $-0.60 * *$ & -0.11 & $-0.44^{\star}$ & 0.34 & 0.27 & 0.02 & 0.28 \\
\hline
\end{tabular}

TABLE 5: Pairwise comparisons of the composition of the Firmicutes phylum at the genus level where ${ }^{*} p<0.01$ and ${ }^{*} p<0.001$. The abbreviation 'ns' refers to not significant.

\begin{tabular}{|c|c|c|c|c|}
\hline & \multicolumn{4}{|c|}{ Biosolid age (weeks) } \\
\hline & Depth 1 (52) & Depth 2 (52) & Depth 1 (208) & Depth 2 (208) \\
\hline Fresh $(0,1$ and 2 weeks pooled $)$ & $\star *$ & $\star \star$ & $\star \star$ & $\star \star$ \\
\hline 52 weeks, Depth 1 & - & * & * & * \\
\hline 52 weeks, Depth 2 & - & - & ns & ns \\
\hline 208 weeks, Depth 1 & - & - & - & ns \\
\hline
\end{tabular}


TABLE 6: SIMPER analysis of the fresh biosolids compared to the 52 weeks biosolids at sampling depth 1.

\begin{tabular}{|c|c|c|c|c|c|}
\hline Taxon & Average dissimilarity & Contribution (\%) & Cumulative (\%) & Mean Fresh & Mean 52 weeks, Depth 1 \\
\hline Tepidimicrobium & 17.62 & 19.53 & 19.53 & 0.08 & 11.10 \\
\hline Bacillus & 13.90 & 15.40 & 34.93 & 0.23 & 9.20 \\
\hline Caldicoprobacter & 10.00 & 11.08 & 46.01 & 0.10 & 6.34 \\
\hline Anoxybacillus & 6.12 & 6.78 & 52.79 & $<0.01$ & 3.56 \\
\hline Desulfotomaculum & 5.71 & 6.32 & 59.11 & 0.03 & 3.62 \\
\hline Paenibacillus & 5.64 & 6.25 & 65.37 & 0.06 & 3.22 \\
\hline
\end{tabular}

TABLE 7: SIMPER analysis of the 52 weeks biosolids sampled at depth 1 compared to depth 2.

\begin{tabular}{|c|c|c|c|c|c|}
\hline Taxon & Average dissimilarity & Contribution (\%) & Cumulative (\%) & Mean 52 weeks, Depth 1 & Mean 52 weeks, Depth 2 \\
\hline Sporosarcina & 3.97 & 12.37 & 12.37 & 1.10 & 6.77 \\
\hline Bacillus & 3.74 & 11.63 & 24.00 & 9.20 & 11.10 \\
\hline Caldicoprobacter & 2.84 & 8.82 & 32.82 & 6.34 & 9.49 \\
\hline Tepidimicrobium & 2.80 & 8.71 & 41.53 & 11.10 & 10.80 \\
\hline Anoxybacillus & 1.93 & 6.01 & 47.55 & 3.56 & 1.37 \\
\hline Clostridium & 1.90 & 5.90 & 53.45 & 2.74 & 4.73 \\
\hline Geobacillus & 1.89 & 5.87 & 59.31 & 2.44 & 4.40 \\
\hline
\end{tabular}

TABLE 8: Shared OTUs between the fresh and stockpiled biosolids. Values in parentheses represent \pm standard error based on relative abundance.

\begin{tabular}{|c|c|c|c|c|c|c|c|}
\hline OTU ID & Phylum & $\begin{array}{c}\text { Classification } \\
\text { level }\end{array}$ & Classification & $\begin{array}{l}\text { Abundance within } \\
\text { the phylum (\%) }\end{array}$ & $\begin{array}{c}\text { Mean times } \\
\text { detected Fresh }\end{array}$ & $\begin{array}{l}\text { Mean times de- } \\
\text { tected } 52 \text { weeks }\end{array}$ & $\begin{array}{c}\text { Mean times detected } \\
208 \text { weeks }\end{array}$ \\
\hline 4 & Actinobacteria & Genus & Mycobacterium & 18.86 & 446.67 (34.26) & $224.00(30.23)$ & 593.33 (71.57) \\
\hline 216 & Actinobacteria & Genus & Microbacterium & 0.95 & $7.44(1.08)$ & $14.17(2.25)$ & $7.80(1.22)$ \\
\hline 84 & Firmicutes & Family & Clostridiaceae & 0.86 & $55.89(4.47)$ & $47.57(6.72)$ & $43.27(5.31)$ \\
\hline 17 & Firmicutes & Family & Clostridiaceae & 1.77 & $135.00(7.08)$ & $86.60(11.50)$ & 93.80 (11.69) \\
\hline 85 & Firmicutes & Genus & Turicibacter & 0.74 & $53.22(3.46)$ & $38.77(5.76)$ & $34.90(5.03)$ \\
\hline 42 & Firmicutes & Family & Clostridiaceae & 1.71 & $127.56(9.09)$ & $81.50(11.86)$ & $90.93(13.47)$ \\
\hline 59 & Proteobacteria & Genus & Mesorhizobium & 3.87 & $44.56(4.33)$ & $126.57(14.43)$ & $58.17(5.35)$ \\
\hline 69 & Proteobacteria & Genus & Hyphomicrobium & 1.70 & $25.56(2.64)$ & $45.27(6.52)$ & $40.90(5.96)$ \\
\hline 898 & Proteobacteria & Genus & Hyphomicrobium & 0.47 & $4.22(0.60)$ & $12.43(3.28)$ & $12.63(2.46)$ \\
\hline 1403 & Proteobacteria & Family & Bradyrhizobium & 0.30 & $4.33(0.71)$ & $5.50(0.67)$ & $8.40(1.45)$ \\
\hline 217 & Proteobacteria & Order & Rhizobiales & 0.41 & $4.11(0.72)$ & $7.57(0.97)$ & $13.87(1.77)$ \\
\hline 578 & Proteobacteria & Genus & Devosia & 0.55 & $2.00(0.37)$ & $15.53(2.53)$ & $14.33(2.10)$ \\
\hline
\end{tabular}

enous microbes (Deng et al., 2019; Trabelsi, Mengoni, Ben Ammar, \& Mhamdi, 2011).

In terms of the physicochemical properties of the fresh and stockpiled biosolids, total $\mathrm{N}$ and total $\mathrm{K}$ were within the range of that found in other studies of $20-80 \mathrm{~g} / \mathrm{kg}$ and $1-6$ $\mathrm{g} / \mathrm{kg}$, respectively (Cogger, Forge, \& Neilsen, 2006). The $\mathrm{P}$ was lower in our study compared to $15-30 \mathrm{~g} / \mathrm{kg}$ measured by Cogger et al. (2006), however we measured plant available $\mathrm{P}$ (Olsen $\mathrm{P}$ ) rather than total $\mathrm{P}$. The biosolids stockpiles accumulate over a period of time, with no turning or aeration and so regions within the stockpiles transition in their exposure to the atmosphere, becoming anaerobic after a period of time being aerobic. The dramatic increase in ammonium content from the fresh biosolids to the older, stockpiled biosolids along with low levels of nitrate indicate a limitation in the oxidation of ammonium to nitrate. The significant increase in $\mathrm{pH}$, ammonium and decrease in nitrate at the two depths in the 52 weeks stockpile indicates the development of environmental and ecological niches while in the 208 weeks stockpile there was more consistency in terms of the physicochemical and bacterial community composition with depth. The decrease in bacterial diversity with increasing biosolids age was likely due to environmental stress induced by high concentrations of ammonium and increased $\mathrm{pH}$ (Lauber, Hamady, Knight, \& Fierer, 2009).

Firmicutes produce endospores and can persist in a wide range of environments for long periods of time, explaining their prevalence in high ammonium and alkaline $\mathrm{pH}$ conditions in our study. The significant shift in the composition of the Firmicutes phylum with stockpiling was attributed primarily to genera Tepidimicrobium and Sporocarcina. Tepidimicrobium is a protein degrader, identified in anaerobic digestates and as also demonstrated here, tolerant to elevated ammonium concentrations (Huang et al., 2013; Li et al., 2017) . Conversely X. Dai et al. (2016) demonstrated a decrease in the abundance of Tepidimicrobium and Firmicutes in general with increasing ammonium stress in 
anaerobic digestion of sewage sludge with the ammonium level artificially raised to $6000 \mathrm{mg} \mathrm{N} / \mathrm{L}$. Tepidimicrobium is a strict anaerobe so is not likely to persist once the biosolids are applied to agricultural land. Sporosarcina requires high ammonium and alkaline $\mathrm{pH}$ conditions for growth. (Mörsdorf \& Kaltwasser, 1989). Species of this genus are commonly found in fertile soils, may produce urease to assist the breakdown of urea and are aerobic or facultatively anaerobic so could persist once the stockpiled biosolids have been distributed from the stockpile (Editorial, 2015). Paenibacillus and Bacillis increased in relative abundance with stockpiling and depending on the species, could be of agricultural benefit if added to an agricultural system. Paenibacillus are known to promote plant growth by a range of strategies including symbiotic N2 fixation, the production of auxin and the control of pathogens (Grady, MacDonald, Liu, Richman, \& Yuan, 2016; McSpadden Gardener, 2004). The Bacillis genus consists of species with a wide range of functions which may be pathogenic or beneficial. Species may be aerobic or facultative anaerobic so may persist either as endospores or functioning bacteria following land application would need to be monitored.

Despite changes in the physicochemical composition of the biosolids with increasing age, agriculturally beneficial nitrogen fixing bacteria belonging to the genus Devosia and Bradyrhizobium (Wolińska et al., 2017) were detected. The abundance of Rhizobium increases with increasing $\mathrm{pH}$ due to increased availability of nutrients such as Mo (Lowendorf, Baya, \& Alexander, 1981). While to our knowledge there have been no previous reports of direct detection in biosolids, a study conducted by Cousin, Grant, Dixon, Beyene, and van Berkum (2002) isolated Bradyrhizobium from soil plots to which biosolids had been applied but not from the untreated control plots. It was concluded that the rhizobium may have been introduced with the biosolids. Although these bacteria represent a relatively small proportion of the phylum, their presence is important for plant growth promotion however their ability to form nodules after application to crops will depend on the species of rhizobium, soil conditions and compatibility with the crop (Slattery \& Pearce, 2001).

The bacterial community in the stockpiled biosolids had a similar composition to that of an anaerobic digester, dominated by Firmicutes with Actinobacteria, Bacteroidetes and Proteobacteria (De Vrieze et al., 2015). In addition to use in agriculture, there could be potential for bioprospecting the biosolids for inoculant for anaerobic digestion and composting (Slimane, Fathya, Assia, \& Hamza, 2014). Bacteria detected in the biosolids including Anoxybacillus, a cellulolytic thermophile, speeds up composting by increasing the duration of the thermophilic phase (Ghaffari, Sepahi, Razavi, Malekzadeh, \& Haydarian, 2011) and likewise, Geobacillus has demonstrated a similar effect (Sarkar et al., 2010).

\section{CONCLUSIONS}

The stockpiled biosolids in this study are an alkaline product with elevated ammonium content and along with the presence of beneficial bacteria make the application of biosolids to agricultural land an attractive option, potentially reducing fertiliser costs and $\mathrm{pH}$ correction in acidic soils. For any valorisation study, pathogen content needs to be monitored. Field trials in a range of soil types are needed to determine the persistence of agriculturally relevant microbes and soil physicochemical properties, particularly $\mathrm{pH}$ and available nutrients such as ammonium, nitrate and phosphorus. This study was limited to one wastewater treatment plant and this could be extended to additional plants and biosolid stockpiles. The potential for using the biosolids as an inoculant for anaerobic digestion and composting could also be investigated.

\section{REFERENCES}

Australian \& New Zealand Biosolids Partnership. (2016). Australian \& New Zealand Biosolids Partnership. Retrieved from https://www. biosolids.com.au/

Bartram, A. K., Lynch, M. D., Stearns, J. C., Moreno-Hagelsieb, G., \& Neufeld, J. D. (2011). Generation of multimillion-sequence 16S rRNA gene libraries from complex microbial communities by assembling paired-end Illumina reads. Applied and environmental microbiology, 77(11), 3846-3852.

Bevacqua, R. F., \& Mellano, V. J. (1993). Sewage sludge compost's cumulative effects on crop growth and soil properties. Compost science \& utilization, 1(3), 34-37.

Bibby, K., \& Peccia, J. (2013). Identification of viral pathogen diversity in sewage sludge by metagenome analysis. Environmental Science \& Technology, 47(4), 1945-1951.

Bibby, K., Viau, E., \& Peccia, J. (2010). Pyrosequencing of the 16S rRNA gene to reveal bacterial pathogen diversity in biosolids. Water Research, 44(14), 4252-4260.

Caporaso, J. G., Kuczynski, J., Stombaugh, J., Bittinger, K., Bushman, F. D., Costello, E. K., . . . Gordon, J. I. (2010). QIIME allows analysis of high-throughput community sequencing data. Nature Methods, 7(5), 335-336.

Cogger, C., Forge, T., \& Neilsen, G. (2006). Biosolids recycling: Nitrogen management and soil ecology. Canadian Journal of Soil Science, 86(4), 613-620.

Cooper, J. L. (2005). The effect of biosolids on cereals in central New South Wales, Australia. 1. Crop growth and yield. Australian Journal of Experimental Agriculture, 45(4), 435-443. doi:http://dx.doi. org/10.1071/EA03099

Cousin, C., Grant, J., Dixon, F., Beyene, D., \& van Berkum, P. (2002). Influence of biosolids compost on the bradyrhizobial genotypes recovered from cowpea and soybean nodules. Archives of Microbiology, 177(5), 427-430. doi:10.1007/s00203-002-0401-y

Dai, X., Yan, H., Li, N., He, J., Ding, Y., Dai, L., \& Dong, B. (2016). Metabolic adaptation of microbial communities to ammonium stress in a high solid anaerobic digester with dewatered sludge. Scientific Reports, 6.

Dai, Z., Liu, G., Chen, H., Chen, C., Wang, J., Ai, S., . . Tang, C. (2019). Long-term nutrient inputs shift soil microbial functional profiles of phosphorus cycling in diverse agroecosystems. The ISME Journal, $1-14$

De Vrieze, J., Gildemyn, S., Vilchez-Vargas, R., Jáuregui, R., Pieper, D. H., Verstraete, W., \& Boon, N. (2015). Inoculum selection is crucial to ensure operational stability in anaerobic digestion. Applied Microbiology and Biotechnology, 99(1), 189-199.

Deng, S., Wipf, H. M.-L., Pierroz, G., Raab, T. K., Khanna, R., \& Coleman-Derr, D. (2019). A Plant Growth-Promoting Microbial Soil Amendment Dynamically Alters the Strawberry Root Bacterial Microbiome. Scientific Reports, 9(1), 1-15.

Edgar, R. C. (2013). UPARSE: highly accurate OTU sequences from microbial amplicon reads. Nature Methods, 10(10), 996-998.

Edgar, R. C., \& Flyvbjerg, H. (2015). Error filtering, pair assembly and error correction for next-generation sequencing reads. Bioinformatics, 31(21), 3476-3482.

Editorial, B. (2015). Sporosarcina. In Bergey's Manual of Systematics of Archaea and Bacteria: John Wiley \& Sons, Ltd. 
EPA Victoria. (2004). Guidelines for Environmental Management, Biosolids Land Application.

Ferraz, A. d. V., Momentel, L. T., \& Poggiani, F. (2016). Soil fertility, growth and mineral nutrition in Eucalyptusgrandis plantation fertilized with different kinds of sewage sludge. New Forests, 47(6), 861-876.

Ghaffari, S., Sepahi, A. A., Razavi, M. R., Malekzadeh, F., \& Haydarian, $H$. (2011). Effectiveness of inoculation with isolated Anoxybacillus sp. MGA110 on municipal solid waste composting process. African Journal of Microbiology Research, 5(30), 5373-5378.

Gómez-Muñoz, B., Magid, J., \& Jensen, L. S. (2017). Nitrogen turnover crop use efficiency and soil fertility in a long-term field experiment amended with different qualities of urban and agricultural waste. Agriculture, Ecosystems \& Environment, 240, 300-313.

Grady, E. N., MacDonald, J., Liu, L., Richman, A., \& Yuan, Z.-C. (2016). Current knowledge and perspectives of Paenibacillus: a review. Microbial Cell Factories, 15(1), 203.

Herrmann, R. F., Grosser, R. J., Farrar, D., \& Brobst, R. B. (2017). Field studies measuring the aerosolization of endotoxin during the land application of Class B biosolids. Aerobiologia. doi:10.1007/ s10453-017-9480-8

Hershey, D. M., Lu, X., Zi, J., \& Peters, R. J. (2014). Functional conservation of the capacity for ent-kaurene biosynthesis and an associated operon in certain rhizobia. Journal of bacteriology, 196(1), 100-106.

Hu, Y., Pang, S., Yang, J., Zhao, X., \& Cao, J. (2019). Changes in soil microbial community structure following amendment of biosolids for seven years. Environmental Pollutants and Bioavailability, 31(1), 24-31. doi:10.1080/26395940.2019.1569478

Huang, Y., Sun, Y., Ma, S., Chen, L., Zhang, H., \& Deng, Y. (2013). Isolation and characterization of Keratinibaculum paraultunense gen. nov., sp. nov., a novel thermophilic, anaerobic bacterium with keratinolytic activity. FEMS Microbiology Letters, 345(1), 56-63. doi:10.1111/1574-6968.12184

Irwin, R., Surapaneni, A., Smith, D., Schmidt, J., Rigby, H., \& Smith, S. R. (2017). Verification of an alternative sludge treatment process for pathogen reduction at two wastewater treatment plants in Victoria, Australia. Journal of water and health, 15(4), 626-637.

Janssen, P. H. (2006). Identifying the dominant soil bacterial taxa in libraries of $16 \mathrm{~S}$ rRNA and 16S rRNA genes. Applied and environmental microbiology, 72(3), 1719-1728.

Karpowicz, E., Novinscak, A., Bärlocher, F., \& Filion, M. (2010). qPCR quantification and genetic characterization of Clostridium perfringens populations in biosolids composted for 2 years. Journal of applied microbiology, 108(2), 571-581.

Klindworth, A., Pruesse, E., Schweer, T., Peplies, J., Quast, C., Horn, M., \& Glöckner, F. O. (2012). Evaluation of general 16S ribosomal RNA gene PCR primers for classical and next-generation sequencing-based diversity studies. Nucleic Acids Research, gks808.

Lauber, C. L., Hamady, M., Knight, R., \& Fierer, N. (2009). Pyrosequencing-based assessment of soil $\mathrm{pH}$ as a predictor of soil bacterial community structure at the continental scale. Applied and environmental microbiology, 75(15), 5111-5120.

Li, N., Xue, Y., Chen, S., Takahashi, J., Dai, L., \& Dai, X. (2017). Methanogenic population dynamics regulated by bacterial community responses to protein-rich organic wastes in a high solid anaerobic digester. Chemical Engineering Journal, 317, 444-453. doi:https:// doi.org/10.1016/j.cej.2017.02.098

Lowendorf, H. S., Baya, A. M., \& Alexander, M. (1981). Survival of Rhizobium in acid soils. Applied and environmental microbiology, 42(6), 951-957.

Martin, M. (2011). Cutadapt removes adapter sequences from high -throughput sequencing reads. EMBnet. journal, 17(1), pp. 10-12.

McSpadden Gardener, B. B. (2004). Ecology of Bacillus and Paenibacillus spp. in Agricultural Systems. Phytopathology, 94(11), 12521258. doi:10.1094/PHYTO.2004.94.11.1252

Mörsdorf, G., \& Kaltwasser, H. (1989). Ammonium assimilation in Proteus vulgaris, Bacillus pasteurii, and Sporosarcina ureae. Archives of Microbiology, 152(2), 125-131. doi:10.1007/bf00456089

Mossa, A.-W., Dickinson, M. J., West, H. M., Young, S. D., \& Crout, N. M. J. (2017). The response of soil microbial diversity and abundance to long-term application of biosolids. Environmental Pollution, 224 16-25. doi:https://doi.org/10.1016/j.envpol.2017.02.056

Nagel, R., Bieber, J. E., Schmidt-Dannert, M. G., Nett, R. S., \& Peters, R. J. (2018). A Third Class: Functional Gibberellin Biosynthetic Operon in Beta-Proteobacteria. Frontiers in Microbiology, 9(2916). doi:10.3389/fmicb.2018.02916
Novinscak, A., DeCoste, N., Surette, C., \& Filion, M. (2009). Characterization of bacterial and fungal communities in composted biosolids over a 2 year period using denaturing gradient gel electrophoresis. Canadian journal of microbiology, 55(4), 375-387.

Novinscak, A., Filion, M., Surette, C., \& Allain, C. (2008). Application of molecular technologies to monitor the microbial content of biosolids and composted biosolids. Water Science and Technology, 57(4), 471-477. doi:10.2166/wst.2008.019

Oliveros, J. C. (2015). VENNY. An interactive tool for comparing lists with Venn Diagrams. 2007. In.

Paez-Rubio, T., Ramarui, A., Sommer, J., Xin, H., Anderson, J., \& Peccia, J. (2007). Emission rates and characterization of aerosols produced during the spreading of dewatered class B biosolids. Environmental Science \& Technology, 41(10), 3537-3544.

Petersen, S. O., Petersen, J., \& Rubæk, G. H. (2003). Dynamics and plant uptake of nitrogen and phosphorus in soil amended with sewage sludge. Applied Soil Ecology, 24(2), 187-195.

Qiong, L., Li, J.-m., Cui, X.-I., \& Wei, D.-p. (2012). On-farm assessment of biosolids effects on nitrogen and phosphorus accumulation in soils. Journal of Integrative Agriculture, 11(9), 1545-1554.

Rouch, D. A., Fleming, V., Deighton, M., Blackbeard, J., \& Smith, S. R. (2008). Evaluating pathogen risks in production of biosolids in Victoria. Paper presented at the AWA Biosolids Specialty IV Conference.

Sarkar, S., Banerjee, R., Chanda, S., Das, P., Ganguly, S., \& Pal, S. (2010). Effectiveness of inoculation with isolated Geobacillus strains in the thermophilic stage of vegetable waste composting. Bioresource Technology, 101(8), 2892-2895.

Schlatter, D. C., Paul, N. C., Shah, D. H., Schillinger, W. F., Bary, A. I., Sharratt, B., \& Paulitz, T. C. (2019). Biosolids and Tillage Practices Influence Soil Bacterial Communities in Dryland Wheat. Microbial Ecology, 78(3), 737-752. doi:10.1007/s00248-019-01339-1

Shange, R. S., Ankumah, R. O., Ibekwe, A. M., Zabawa, R., \& Dowd, S. E. (2012). Distinct Soil Bacterial Communities Revealed under a Diversely Managed Agroecosystem. PloS one, 7(7), e40338. doi:10.1371/journal.pone.0040338

Slattery, J., \& Pearce, D. (2001). The impact of background rhizobia populations on inoculation response. Inoculates and nitrogen fixation of legumes in Vietnam. ACIAR Proceeding(109e), 37-45.

Slimane, K., Fathya, S., Assia, K., \& Hamza, M. (2014). Influence of Inoculums/Substrate Ratios (ISRs) on the Mesophilic Anaerobic Digestion of Slaughterhouse Waste in Batch Mode: Process Stability and Biogas Production. Energy Procedia, 50, 57-63. doi:http://dx.doi org/10.1016/j.egypro.2014.06.007

Tamoutsidis, E., Papadopoulos, I., Tokatlidis, I., Zotis, S., \& Mavropoulos, T. (2002). Wet sewage sludge application effect on soil properties and element content of leaf and root vegetables. Journal of plant nutrition, 25(9), 1941-1955.

Trabelsi, D., Mengoni, A., Ben Ammar, H., \& Mhamdi, R. (2011). Effect of on-field inoculation of Phaseolus vulgaris with rhizobia on soil bacterial communities. FEMS Microbiology Ecology, 77(1), 211-222. doi:10.1111/j.1574-6941.2011.01102.x

Viau, E., \& Peccia, J. (2009a). Evaluation of the enterococci indicator in biosolids using culture-based and quantitative PCR assays. Water Research, 43(19), 4878-4887.

Viau, E., \& Peccia, J. (2009b). Survey of wastewater indicators and human pathogen genomes in biosolids produced by class $A$ and class B stabilization treatments. Applied and environmental microbiology, 75(1), 164-174.

Warman, P., \& Termeer, W. (2005). Evaluation of sewage sludge, septic waste and sludge compost applications to corn and forage: yields and N, P and K content of crops and soils. Bioresource Technology, 96(8), 955-961.

Wolińska, A., Kuźniar, A., Zielenkiewicz, U., Banach, A., Izak, D., Stępniewska, Z., \& Błaszczyk, M. (2017). Metagenomic Analysis of Some Potential Nitrogen-Fixing Bacteria in Arable Soils at Different Formation Processes. Microbial Ecology, 73(1), 162-176.

Yergeau, E., Masson, L., Elias, M., Xiang, S., Madey, E., Huang, H., . . Beaudette, L. (2016). Comparison of Methods to Identify Pathogens and Associated Virulence Functional Genes in Biosolids from Two Different Wastewater Treatment Facilities in Canada. PloS one, 11(4), e0153554. doi:10.1371/journal.pone.0153554 